\title{
Research on Debt Financing Influencing Factors of China Shipping Supply Chain Enterprises
}

\author{
Yiqiu Wen ${ }^{a}$ \\ School of Economics and Management, Northeast Agricultural University, Harbin 150030, China. \\ a 764643317@qq.com
}

Keywords: Shipping supply chain, Debt financing, Multiple regressions.

\begin{abstract}
Based on the MM theory, the financial data between 2013 and 2016 is chosen from 31 listed shipping supply chain enterprises in the paper, to empirically analyze the influencing factors of debt financing ways for China shipping supply chain enterprises. The main conclusions of this paper were as follows: (1) For the profitability, return on net assets ratio exerts a significant positive impact on the debt financing ways of the shipping supply chain enterprises. (2) For the repaying capability, the current ratio and shareholders' equity ratio have a significant negative effect on the debt financing ways of the shipping supply chain enterprises; nevertheless, the quick ratio makes a significant positive difference in the debt financing ways of the shipping supply chain enterprises; (3) For the operational capabilities, the fixed assets ratio has a significant negative impact on the debt financing ways of the shipping supply chain enterprises; while days sales of inventory wields a significant positive influence on the debt financing ways of the shipping supply chain enterprises.
\end{abstract}

\section{Introduction}

There is no commonly accepted understanding for the factors affecting the capital structure, and the riddles of the capital structure remain unlocked. Therefore, it has always been an important task for academics to explore the influencing factors of capital structure. However, the complexity of the capital structure results in the non-uniform research conclusion. Therefore, this article will explore the influencing factors from debt financing ways, which is one aspect of the capital structure. In addition, China now is redoubling its efforts to encourage inclusive finance and is committed to helping SMEs to solve the financing problems. However, the limitation of ship leasing objects makes it more difficult for shipping supply chain enterprises to finance than that of the ordinary SMEs. Therefore, the research on debt financing influencing factors of China shipping supply chain enterprises has certain theoretical significance.

\section{Literature Review}

Among the existing relevant studies about influencing factors of capital structure, the most representative ones were Titman and Wessels (1988), Rajan and Zingales (1995), Booth (2001), etc.

According to the different theories of capital structure, Titman and Wessels (1988) proposed that the capital structure could be influenced by the growth, the industry, the volatility and the profitability of the enterprises. The conclusion was that there was a negative correlation between the enterprise characters and the debt level. The choice of capital structure might depend on transaction costs, and the floating debt ratio was negatively correlated with enterprise scale, in other words, the small-scale enterprises were likely to cost more; and the enterprise debt ratio was negatively correlated with profitability. However, Titman and Wessels did not identify the basis for supporting the impact of volatility, non-debt tax shield, growth or guarantee value on the debt ratio.

Rajan and Zingales (1998) selected four indicators to study the influencing factors of capital structure, namely, tangible assets ratio, firm size, growth opportunity and profitability. Using the enterprises samples from seven industrialized countries, the study found that the tangible assets ratio had a positive correlation with the leverage; growth opportunities were negatively correlated with the leverage ratio in all seven countries; however, the impact of indicators on capital structure in different 
countries was not the same. The research showed that the firm size was negatively correlated with the leverage ratio in Germany, while samples from France and Italy showed firm size variables were not significant.

Booth, Aivazian (2001) and other experts analyzed the cases of developing countries and developed countries as comparative samples. In these studies, different models were used to find the variables of the capital structure from two sample groups; and different liability and equity indicators were used in accordance with the different enterprise characteristics and its institutional differences. In the tradeoff model, the influencing factors were tax rate, commercial risks, asset types and profitability. In the agency theory, the conflict theory between insiders and outside investors could explain the capital structure differences variables. In the Pecking Order Theory, the imperfection of financial markets represented the key factor affecting the capital structure.

The test showed that the factors affecting the choice of capital structure in developing and developed countries were basically the same in the case of nontransparent transaction costs and asymmetric information; however, it was also pointed out that even the same variables might be affected by different national factors, such as inflation rate, GDP growth rate, capital market development, etc. overall, in the studies of capital structure, Booth (2001) and other experts expanded the research scope from developed countries to developing countries, thus verifying the wider applicability of the theory.

Moraes and Moraes (2003) conducted a regression analysis of Brazilian manufacturing enterprises and concluded the three factors of influencing enterprise's capital structure respectively as follows: enterprise scale, production and operation cycle, and asset composition.

Beck, Demirgüç-Kunt and other experts (2008) investigated SMEs in 48 countries and found that the enterprise scale was the most crucial factor influencing the choice of financing ways, as it was difficult for the smaller enterprises to secure the financing from banks and other financial institutions, while larger business was much easier.

At present, the latest researches in China focused more on the following parts:

Firstly, Zhu Jianqi, Lin Zelan and other experts (2018) compared SME financing services in mainland China with that in Taiwan. They found that SMEs in mainland China lacked policy-oriented banks, and the financing guarantee system was far from being perfect. Besides, there was a large amount of special funds but limited industrial funds, the credit reporting source was relatively decentralized, and "counseling" was insufficient, etc. Given consideration of supply chain members and supply chain system, Zhan Ji'Zhou and Shu Youguo (2017) explored the selection strategies of supplier financing ways. They found that accounts receivable financing was more predominate when the interest rate of bank loans was relatively low and retailers with higher lending rates had advantage in prepayment.

The empirical results were as follows: using logit regression, Liu Guangsheng and Yue Fangfang (2017) analyzed the refinancing ways influencing factors of listed companies in China. They found that the high grow listed companies with good operation ability tended to refinance their equity; those with strong repaying capability, good performance and paying attention to the control benefit tended to refinance the convertible bonds. The growth, repaying capability, profitability and ownership structure of the enterprises posed a notably significant impact on the choice of refinancing ways. Based on the dynamic tradeoff theory of capital structure and market timing theory, Li Jinglin (2017) found that the target capital structure and stock market mispricing played an important role in the choice of M \& A financing ways.

The existing literature on the capital structure mainly focuses on the listed companies and mediumsized enterprises and small ones. The financial indicators are initially paid attention to, and the case studies are the research methods. Due to the lack accessibility of the data, there was relatively little empirical analysis.

Based on the MM theory, China's shipping supply chain enterprises are targeted in the paper. The shipping supply chain enterprises in Shanghai and Shenzhen will be taken for instance to empirically study the influencing factors of the debt financing ways. 


\section{Research Methods}

\subsection{Sample Selection and Data Sources}

Given consideration of the feasibility of research and the reliability and availability of data, the shipping supply chain enterprises were selected as the research object. All selected enterprises were listed before 2013 for obtaining continuous financial data from 2013-2016. All financial data taken from Net Ease Finance database are collected manually.

Meanwhile, the following types of enterprises should be excluded for the needs of research:

ST (Special Treatment) listed enterprises, PT (Particular Transfer) listed enterprises, and delisting enterprises.

ST and PT listed enterprises were excluded here on the account of their inside financial and other irregularities.

Listed enterprises after 2013.

The enterprises with fragmentary data and data values exceeding the average range were also excluded. In the process of collecting information, some data are inevitable to miss during the past four years, in other words, some financial data are not included in. As a result, the missing and abnormal data were taken out to avoid affecting the empirical results.

According to the above principles, 31 shipping supply chain listed enterprises between 2013 and 2016 were selected as samples after some adjustments. 124 observed values from 31 enterprises were finally obtained as research samples for descriptive statistics when all data of selected enterprises during the four-year were collected. The sample data index statistic caliber is the annual disclosed data of the Enterprises Annual report.

\subsection{Model Construction}

\subsubsection{Econometric Model}

The multiple regression model was used in the research based on the obtained data features and research need. The following is a brief description of the multiple regression model. The specific form is as follows:

$$
\mathrm{yt}=\beta 0+\beta 1 \mathrm{xt} 1+\beta 2 \mathrm{xt} 2+\ldots+\beta \mathrm{k}-1 \mathrm{xt} \mathrm{k}-1+\mathrm{ut},
$$

$y t$ the explained variable (dependent variable) $x t j$ : the explanatory variable (independent variable); ut: the stochastic error; $\beta \mathrm{i}, \mathrm{i}=0,1, \ldots, \mathrm{k}-1$ : the regression parameter (usually unknown)

Research Model

The author, based on the experience from predecessors, selected DAR(debt-to-assets ratio) as the explained variable, and Rona(return on net assets), EPS(earnings per share), $\operatorname{Fr}$ (flow ratio), Qr(quick ratio), Ser(shareholders' equity ratio), Poofa(proportion of the fixed assets), Mbigr(main business income growth rate), Art(accounts receivable turnover), and Itd(inventory turnover days) as the explaining variable to prove the research assumption. The specific form is as follows: $\mathrm{DARt}=\beta 0+\beta 1$ Ronat $1+\beta 2$ EPSt $2+\beta 3$ Frt $3+\beta 4$ Qrt $4+\beta 5$ Sert $5+\beta 6$ Proofat $6+\beta 7$ Mbigrt $7+\beta 8$ Artt $8+\beta$ IItd

$$
9+\text { ut, }
$$

yt: the explained variable; $x t j$ : the explanatory variable; $u t:$ the stochastic error; $\beta \mathrm{i}, \mathrm{i}=0,1, \ldots, \mathrm{k}-1$ : the regression parameter

\subsection{Variable Selection}

\subsubsection{Explained Variable}

The DAR (debt-to-assets ratio) of enterprises indicates the ratio of total liabilities to total assets, which can be used to measure the amount of debt financing of enterprises. That is to say: Higher DAR (debt-to-assets) can bring more debt financing for enterprises.

\subsubsection{Explanatory Variable}

Rona (return on net assets) indicates the ratio of earnings before interest and tax to the average total net assets.

EPS (earnings per share) shows the ratio of current net assets of ordinary shareholders to the weighted average common shares outstanding during the year.

Fr (flow ratio) means the ratio of current assets to current liabilities.

Qr (quick ratio) is the ratio of quick assets to current liabilities.

Ser (shareholders' equity ratio) reflects the ratio of shareholders' equity to total assets. 
Poofa (proportion of the fixed assets) reveals the ratio of fixed assets to total assets.

Mbigr (main business income growth rate) indicates the ratio of increase in operating receipt of enterprises during the year to the gross revenue the last year.

Art (accounts receivable turnover) explains the ratio of operating receipt to average accounts receivable balance.

Itd (inventory turnover days) expresses the ratio of COGS (cost of goods sold) to average inventory balances.

Table 1. The Variable Declaration of the Study

\begin{tabular}{|c|c|c|c|c|}
\hline & Variable name & Formula & unit & $\begin{array}{l}\text { Variable } \\
\text { type }\end{array}$ \\
\hline \multirow[b]{2}{*}{ Profitability } & $\begin{array}{l}\text { Return on net } \\
\text { assets(Rona) }\end{array}$ & $\begin{array}{c}\text { earning before interest and tax/average total } \\
\text { net assets } \times 100 \%\end{array}$ & $\%$ & $\begin{array}{l}\text { continuous } \\
\text { type }\end{array}$ \\
\hline & $\begin{array}{l}\text { Earning per } \\
\text { share(EPS) }\end{array}$ & $\begin{array}{l}\text { current net assets of ordinary } \\
\text { shareholders/weighted average common shares } \\
\text { outstanding during the year }\end{array}$ & Yuan & $\begin{array}{l}\text { continuous } \\
\text { type }\end{array}$ \\
\hline \multirow{4}{*}{$\begin{array}{l}\text { Repaying } \\
\text { Capability }\end{array}$} & Flow ratio(Fr) & current assets/current liability $\times 100 \%$ & $\%$ & $\begin{array}{l}\text { continuous } \\
\text { type }\end{array}$ \\
\hline & Quick ratio(Qr) & quick assets/current liability $\times 100 \%$ & $\%$ & $\begin{array}{l}\text { continuous } \\
\text { type }\end{array}$ \\
\hline & $\begin{array}{l}\text { shareholders' } \\
\text { equity ratio(Ser) }\end{array}$ & shareholders' equity/total assets $\times 100 \%$ & $\%$ & $\begin{array}{l}\text { continuous } \\
\text { type }\end{array}$ \\
\hline & $\begin{array}{l}\text { proportion of the } \\
\text { fixed } \\
\text { assets(Poofa) }\end{array}$ & Fixed assets/total assets $\times 100 \%$ & $\%$ & $\begin{array}{l}\text { continuous } \\
\text { type }\end{array}$ \\
\hline \multirow{3}{*}{$\begin{array}{l}\text { Operation } \\
\text { Capability }\end{array}$} & $\begin{array}{l}\text { main business } \\
\text { income growth } \\
\text { rate(Mbigr) }\end{array}$ & $\begin{array}{l}\text { (main business income during the year-main } \\
\text { business income the last year)/main business } \\
\text { income the last year } \times 100 \%\end{array}$ & $\%$ & $\begin{array}{l}\text { continuous } \\
\text { type }\end{array}$ \\
\hline & $\begin{array}{l}\text { accounts } \\
\text { receivable } \\
\text { turnover(Art) }\end{array}$ & $\begin{array}{c}\text { Operating receipt/average accounts receivable } \\
\text { balance } \\
\text { Of which average accounts receivable } \\
\text { balance }=(\text { accounts receivable balance at the } \\
\text { beginning of the year }+ \text { accounts receivable } \\
\text { balance at the end of the year }) / 2\end{array}$ & $\%$ & $\begin{array}{l}\text { continuous } \\
\text { type }\end{array}$ \\
\hline & $\begin{array}{c}\text { inventory turnover } \\
\text { days(Itd) }\end{array}$ & Cost of goods sold/average inventory balances & Day & $\begin{array}{l}\text { continuous } \\
\text { type }\end{array}$ \\
\hline
\end{tabular}

\section{Empirical Analysis}

\subsection{Descriptive Statistics}

Stata13 were used as a tool to make the descriptive statistics for the 124 samples of main variables (see table 2). The specific statistical results are as follows: DAR(debt-to-assets ratio)'s mean value is 50.01 with maximum value 89.10 and least value 4.70; Rona(return on net assets)'s mean value is 37.93 with maximum value 154.83 and least value -57.21 ; EPS(earning per share)'s mean value is 0.16 with maximum value 1.42 and least value -1.89 ; Fr (flow ratio)'s mean value is 3.46 with maximum value 254.21 and least value 0.25; Qr (quick ratio)'s mean value is 1.42 with maximum value 43.53 and least value 0.23 ; Ser (Shareholders' equity ratio)'s mean value is 49.37 with maximum value 92.32 and least value 10.81; Poofa (Proportion of the fixed assets)'s mean value is 38.69 with maximum value 126.72 and least value 1.71; Mbigr (main business income growth rate)'s mean value is 17.63 with maximum value 480.58 and least value -83.01 ; Art(accounts receivable turnover)'s mean value is 12.80 with maximum value 76.49 and least value 1.12 ; Itd (inventory turnover days)'s mean value is 117.66 with maximum value 831.22 and least value 4.37. 
Table 2. Descriptive Statistics

\begin{tabular}{cccccc}
\hline Variables & Samples & Mean Value & Standard Deviation & Least Value & Maximum Value \\
\hline DAR & 124 & 50.01 & 18.46 & 4.70 & 89.19 \\
Rona & 124 & 37.93 & 22.74 & -57.21 & 154.83 \\
EPS & 123 & 0.16 & 0.37 & -1.89 & 1.42 \\
Fr & 124 & 3.46 & 22.73 & 0.25 & 254.21 \\
Qr & 124 & 1.42 & 3.91 & 0.23 & 43.53 \\
Ser & 124 & 49.37 & 18.21 & 10.81 & 92.32 \\
Poofa & 121 & 38.69 & 22.54 & 1.71 & 126.72 \\
Mbigr & 124 & 17.63 & 66.14 & -83.01 & 480.58 \\
Art & 124 & 12.80 & 13.25 & 1.12 & 76.49 \\
Itd & 124 & 117.66 & 138.13 & 4.37 & 831.22 \\
\hline
\end{tabular}

\subsection{Regression Analysis}

The results of regression analysis in this paper are shown in table 3. From this table, a regression analysis was made by model (1) to (3) on debt financing of shipping supply chain enterprises with the usage of key variables of profitability, repaying profitability and operation capability. Model (4) to (6), under the way of making use of variables from two major combined capabilities among the three, ran a regression on shipping supply chain enterprises. As for model (7), all key variables were used by this model for a regression analysis. The model(7) shows that the regression coefficient of Roa (return on net assets) to the debt financing ways of shipping supply chain enterprises is 0.0008 with a remarkable level under 10\%; the regression coefficient of $\mathrm{Fr}$ (flow ratio) to the debt financing way of shipping supply chain enterprises is -3.71 with a remarkable level under $1 \%$; the regression coefficient of Qr (quick ratio) to the debt financing ways of shipping supply chain enterprises is 0.409 with a remarkable level under 1\%; the regression coefficient of Ser (shareholders' equity ratio) to the debt financing ways of shipping supply chain enterprises is -0.997 with a remarkable level under $1 \%$; the regression coefficient of Poofa (proportion of the fixed assets) to the debt financing ways of shipping supply chain enterprises is -0.0027 with a remarkable level under $10 \%$; and the regression coefficient of Itd (inventory turnover days) to the debt financing ways of shipping supply chain enterprises is 0.004 with a remarkable level under $1 \%$. See table 3 for other details.

Table 3. regression analysis

\begin{tabular}{|c|c|c|c|c|c|c|c|}
\hline Variables & (1)AL & (2)AL & (3)AL & (4)AL & (5)AL & (6)AL & (7)AL \\
\hline Rona & $\begin{array}{l}0.322 * * * \\
(0.0845)\end{array}$ & & & $\begin{array}{c}0.0002 \\
(0.0006)\end{array}$ & $\begin{array}{c}0.442 * * * \\
(0.116)\end{array}$ & & $\begin{array}{l}0.0008^{*} \\
(0.0004)\end{array}$ \\
\hline EPS & $\begin{array}{c}-13.54 * * * \\
(4.549)\end{array}$ & & & $\begin{array}{l}-0.0177 \\
(0.0415)\end{array}$ & $\begin{array}{c}-16.36^{* * *} \\
(4.619)\end{array}$ & & $\begin{array}{l}-0.0311 \\
(0.0275)\end{array}$ \\
\hline $\mathrm{Fr}$ & & $\begin{array}{c}-0.369 * * * \\
(0.0033)\end{array}$ & & $\begin{array}{c}-0.369 * * * \\
(0.0032)\end{array}$ & & $\begin{array}{c}-0.372 * * * \\
(0.0034)\end{array}$ & $\begin{array}{c}-0.371 * * * \\
(0.0034)\end{array}$ \\
\hline Qr & & $\begin{array}{c}0.400 * * * \\
(0.0194)\end{array}$ & & $\begin{array}{c}0.397 * * * \\
(0.0190)\end{array}$ & & $\begin{array}{c}0.411 * * * \\
(0.0197)\end{array}$ & $\begin{array}{c}0.409 * * * \\
(0.0197)\end{array}$ \\
\hline Ser & & $\begin{array}{c}-0.997 * * * \\
(0.0009)\end{array}$ & & $\begin{array}{c}-0.997 * * * \\
(0.0014)\end{array}$ & & $\begin{array}{c}-0.998 * * * \\
(0.0008)\end{array}$ & $\begin{array}{c}-0.997 * * * \\
(0.0011)\end{array}$ \\
\hline Poofa & & $\begin{array}{c}-0.00421 * * * \\
(0.0005)\end{array}$ & & $\begin{array}{c}-0.0044 * * * \\
(0.0006)\end{array}$ & & $\begin{array}{c}-0.0024 * * * \\
(0.0008)\end{array}$ & $\begin{array}{c}-0.0027 * * * \\
(0.0008)\end{array}$ \\
\hline Mbigr & & & $\begin{array}{c}0.0171 \\
(0.0224)\end{array}$ & & $\begin{array}{c}0.0537 * * * \\
(0.0180)\end{array}$ & $\begin{array}{l}8.00 \mathrm{e}-05 \\
(0.0001)\end{array}$ & $\begin{array}{c}0.000131 \\
(0.0001)\end{array}$ \\
\hline Art & & & $\begin{array}{l}-0.0763 \\
(0.290)\end{array}$ & & $\begin{array}{r}-0.0222 \\
(0.197)\end{array}$ & $\begin{array}{c}0.0003 \\
(0.0007)\end{array}$ & $\begin{array}{c}0.0005 \\
(0.0006)\end{array}$ \\
\hline Itd & & & $\begin{array}{c}0.0242 \\
(0.0161)\end{array}$ & & $\begin{array}{c}0.0485 * * * \\
(0.0139)\end{array}$ & $\begin{array}{c}0.0004 * * \\
(0.0002)\end{array}$ & $\begin{array}{c}0.0004 * * * \\
(0.0002)\end{array}$ \\
\hline Con & $\begin{array}{c}39.62 * * * \\
(4.691)\end{array}$ & $\begin{array}{l}100.1 * * * \\
(0.0494)\end{array}$ & $\begin{array}{c}47.84 * * * \\
(5.165)\end{array}$ & $\begin{array}{l}100.1 * * * \\
(0.0730)\end{array}$ & $\begin{array}{c}29.18 * * * \\
(7.517)\end{array}$ & $\begin{array}{l}100.0 * * * \\
(0.0632)\end{array}$ & $\begin{array}{c}99.95 * * * \\
(0.0793)\end{array}$ \\
\hline $\begin{array}{c}\text { Observations } \\
\mathrm{R}^{2}\end{array}$ & $\begin{array}{c}123 \\
0.215\end{array}$ & $\begin{array}{c}121 \\
1.000\end{array}$ & $\begin{array}{c}124 \\
0.045\end{array}$ & $\begin{array}{c}121 \\
1.000\end{array}$ & $\begin{array}{c}123 \\
0.367\end{array}$ & $\begin{array}{c}121 \\
1.000\end{array}$ & $\begin{array}{c}121 \\
1.000\end{array}$ \\
\hline
\end{tabular}




\section{Main Conclusions and Reasons}

\subsection{Main Conclusions}

The main research conclusions are as below: First, the regression coefficient of Rona (return on net assets) to the debt financing ways of shipping supply chain enterprises is positive number with a remarkable level under $10 \%$ for profitability. Second, the regression coefficient of Fr (flow ratio) or Ser (shareholders' equity ratio) to the debt financing ways of shipping supply chain enterprises are negative number with a remarkable level under $1 \%$ and the regression coefficient of Qr (quick ratio) to the debt financing ways of shipping supply chain enterprises is positive number with a remarkable level under $1 \%$ for repaying capability. Third, the regression coefficient of Poofa (proportion of fixed assets) to the debt financing ways of shipping supply chain enterprises is negative number with a remarkable level under 10\%; the regression coefficient of Itd (inventory turnover days) to the debt financing ways of shipping supply chain enterprises is positive number with a remarkable level under $1 \%$ for operation capability.

\subsection{Reason Analysis}

The reasons of the conclusions in the paper are as follows:

One contributing factor is about profitability. Better profits are enjoyed by shipping supply chain enterprises if they have higher DAR (debt-to-assets). Therefore, the banks and investors are inclined to put their money into such enterprises. In addition, more accessible investment channels multiply the possibilities to choose debt financing by shipping supply chain enterprises.

The second one is about repaying capability. These shipping supply chain enterprises with higher Fr (flow ratio) stand a stronger cashability of current assets in a short term. Therefore, they are not willing to choose debt financing. While those enterprises with higher Qr (quick ratio) enjoy a stronger cashability of quick assets and ability to repay short-term debt thus freeing them from the risk on their control rights. Therefore, these enterprises tend to choose debt financing. As the higher Ser (shareholders' equity ratio), the weaker the repaying capability of shipping supply chain enterprises. Such enterprises are reluctant to choose debt financing.

The third reason is about operation capability. If a shipping supply chain corporation possesses higher Poofa (proportion of fixed assets) and lower spare capital, it will own a stronger operation capability. Therefore, it is less likely for shipping supply chain enterprises to choose debt financing. On the other hand, the shipping supply chain enterprises with more inventory turnover days (Itd) will speed up its stock values realization, which promises such enterprises enjoy a stronger potential repaying capability. In consequence, these enterprises prefer to choose debt financing.

\section{References}

[1]. Beck, T. and A. Demirgüç-Kunt, et al. (2008). "Financing patterns around the world: Are small enterprises different." Journal of Financial Economics 89 (3): 467-487.

[2]. Booth, L. and V. Aivazian, et al. (2001). "Capital Structures in Developing Countries." Journal of Finance 56 (1): 87-130.

[3]. Moraes, M. and M. J. B. D. Moraes (2003). "O ensino de enfermagem em saúde coletiva: redescobrindo caminhos para novas práticas.".

[4]. Rajan, R. G. and L. Zingales (1998). "WHICH CAPITALISM? LESSONS FORM THE EAST ASIAN CRISIS." Journal of Applied Corporate Finance 11 (3): 40-48.

[5]. Titman, S. and R. Wessels (1988). "The Determinants of Capital Structure Choice." Journal of Finance 43 (1): 1-19.

[6]. Liu Guangsheng \& Yue Fangfang (2017). "Enterprise Characteristics and the Choice of Refinancing Way: Based on the Empirical Data of Chinese Listed Companies from 2007 to 2015." On Economic Problems (08): 50-55+62. 
[7]. Zhan Jizhou \& Shu Youguo (2017). "Choice of Financing Strategies with Suppliers Production Capital Constraint." Journal of System \& Management (04): 779-786.

[8]. Zhu Jianqi \& Lin Zelan (2018)."A Study on the Solutions to Financing Difficulties of Small and Medium-sized Enterprises-Based on Taiwan's Experience and Implications." Periodical of Ocean University of China (Social Sciences) (01): 77-89. 